\title{
Corporate Social Responsibility and the Performance of Commercial Banks in Kenya: A Case of Equity Bank
}

\author{
Mercy Wanja Mwangi ${ }^{1}$ and Dr. Jane Wanjira ${ }^{2}$ \\ ${ }^{1}$ MBA student, Kenyatta University, School of business \\ ${ }^{2}$ Lecturer, department of Business Administration, School of Business, Kenyatta University
}

\begin{abstract}
The goal of this study was to explore the influence of Social Corporate Responsibility on organization Performance. It specifically sought to establish the influence of philanthropic CSR activities benefits salient to CSR activities CSR contributions and financial-focused CSR on Equity Bank performance. This study was guided by three theories namely Triple Bottom Line Theory, the Stakeholder Theory as well as the Fiduciary Capitalism Theory. This study adopted a descriptive research design. With all the 238 management staff at Equity Bank being the target population. In order to answer the research questions, the study incorporated merits of secondary data which formed a basis for comparison with findings. The findings of the study were: philanthropic CSR, benefit salient, CSR contributions and financial focused CSR, had a significant influence on organizational performance of commercial banks in Kenya. The study concludes that: Philanthropic CSR, benefit salient on CSR, CSR contributions and financial focused CSR activities had a positive and significant influence on Equity Bank organizational performance. The study thus makes the following recommendations that Equity bank management should continue to invest more in the corporate social responsibility aspect done to make the life of beneficiaries better in terms of education, health and other humanistic endeavors. They should improve on strategies that improves on the desired outcomes that accrue out of CSR activities and improve by seminars and involvement actions how the employees feel about CSR enough to warrant motivation to better productivity by them.
\end{abstract}

Key Words: Corporate Social Responsibility, Organization Performance, Commercial Banks in Kenya, Equity Bank

DOI: 10.7176/ijcab.v3iII.17, URN urn:nbn:de:0000ijcab.v3iII.177

\section{Cite this Article:}

Mwangi, M., \& Wanjira, J. (2019). Corporate Social Responsibility and the Performance of Commercial Banks in Kenya: A Case of Equity Bank. International Journal of Current Aspects, 3(II), 186-198. http://journals.ijcab.org/journals/index.php/ijcab/article/view/17

\section{INTRODUCTION}

There have been several reports of tough times for the banking industry both globally and in African Countries like Kenya. To improve the efficiency of banks, organizations have embraced different types of strategies from technological innovations to strategies dealing with competition and marketing. Corporate Social Responsibility is among one of the most used strategies in various organizations. Scholars have attempted to describe the main reason why commercial entities would voluntarily interact with the social welfare of others through their activities. (Bowen, 1953) state that most companies participate in activities that are voluntary and social 
simply as a means to place themselves as legitimate members in a society and shore up the performance of their organizations in the long-run. Empirical research has assessed the achievements of banks and their general status across the world and found out that the current venture into advanced financial activities has ushered in a rise in risk and decreased income (De Young \& Roland, 2011; Goddard, Smith \& Markus, 2012; and Stiroh \& Rumble, 2016). An eccentric picture tends to come up outside the US. Smith et al. (2003) investigated the general achievement of selected banks in 15 countries across the EU and concluded that noninterest income has become fickle compared to interest income and thus banks in Europe were not performing better. They also found a negative correlation between two income streams of banks which led to a conclusion different from the studies in the US, that income not generated from interests stabilizes bank income. This in a way illustrates why in Europe, big banking institutions have a superior performance (in comparison of market-based measures) across an uninterrupted time frame compared to the small banks (Baele, Oron \& Ovile, 2011). However, evidence from other parts of Europe shows that it's riskier for small banking institutions to venture into income activities that do not rely on interests than to center on the traditional business areas (Mercieca, Armstrong \& Erin, 2011).

Generally, some of the first world countries like the USA are undergoing a major banking crisis with the Citibank group recording an excess of 40 billion dollars in losses (Elliot 2016). However, Canadian Banks have been able to withstand the challenges in the global financial market with Elliot (2016) crediting this to regulatory discipline as well as the cultural mindset that is present among banks in Canada. Most scholars have majored their studies on Specific European Countries. In their study, Acharya, et al. (2012), sampling from the Italian banks, find that performance of banks has improved due to the new incursion into the diversity of assets across bank loan portfolios. Hayden et al. (2012), used data from several German banking institutions and their specific bank loan portfolios in order to assess the degree to which the banking activities available in different organizations and areas improved efficiency. They found few benefits, with all current activities being key todecreasing bank efficiency. In the most inclusive similar study by Laeven and Levine (2011), the authors assess how banking activities affected the value of major banking institutions in 42 countries. Their main findings werethe selling value of banking and other financial services firms is mostly lesser than that of specialized organizations and institutions. Therefore, the benefits of the economies of scope may not be enough to allow most banks in Europe and the USA to perform at their peak.

Across Africa, Kirkpatrick, Murinde, and Tefula (2014) performed an empirical study of 89 commercial banks from several African countries from the year 2001 to 2014. The findings of the study was that banks are usually on an average of $65 \%$ profit efficiency and $80 \%$ cost efficiency with reference to the DFA and SFA merits. The study by Kirkpatrick, Murinde, and Tefula (2014) also suggest that the penetration of foreign banks in Africa has yielded more foreign owed banks thus leading to reduced profits and the x-efficiency of most African Banks. Conclusively, it can be argued that banking performance in Africa is better when it is still domesticated as opposed to foreign entry in its management. The Kenyan situation is no different. The banking industry in Kenya has undergone great changes in the costs of financial assets it holds in the past decade. The amount of loans being given in banks have been greatly affected by both external and internal factors. According to the Central Bank Report (2016), the existing proportion of gross advances to total industry assets of is $57 \%$ and $55 \%$ as at December 2008and December 2011 respectively. The biggest challenge being experienced by most 
commercial banks in Kenya is the attempt to increase the amount of non-performing assets. This mainly due to the fact that the said assets have to be accounted for in any financial institution's income or they can be written off thus creating a major impact on the performance of the entire banking sector. A vigorous banking sector is characterized by its ability to cope with adverse economic shocks and its ability to contribute to the stability of the entire financial sector and the economy at large (Business intelligence 2014).

\subsection{Corporate Social Responsibility}

It's the role of each particular organization to participate in CSR in an attempt to sustain an equilibrium between the economy and the ecosystems. The equilibrium should be evident among economic development as well as the welfare of both the society and the environment. Holme and Watts (2000) described CSR as the pledge or obligation to have an ethical policy and practice that allows for economic progress for the company, the society and individuals that stand to gain something, either directly or indirectly, from such an engagement. This is done in such a way that also allows governments to partner with similar minded businesses and the businesses stand to gain by allowing it to get tax reprieve among other benefits. Galbreath (2012), on his part categorized CSR in the form of ethical, legal, economic options and philanthropic endeavors. CSR all about the relationship between the business world and the society, and how the companies relates with its stakeholders i.e.: employees, buyers, investors, suppliers, local community and special interest groups (Carroll, 2011). Therefore, CSR is how an organization reacts to its social plans.

\subsection{Organizational Performance}

Chong (2008) illustrates several approaches used to determine the organization's performance. These are the system resource method, goal method, stakeholder method coupled with competitive value method. Stakeholder approach together with the competitive value style, appraise performance of a firm premised on external stakeholders' satisfaction e.g. suppliers, customers', competitors. It aims at the ability of an organization to meet its stakeholders' expectations and needs. Goal approach is commonly used since it is simple, understandable and focusses on internal objectives (Chong, 2008; Zahra, 2012). Managers are able to access whatever information they need for purposes of the evaluation. This approach is all about the extent to which an organization achieves its objectives. System resource approach on the other hand assesses an organization's ability to obtain the necessary resources. According to Richard et al. (2008), the goal approach directs the owners-managers be more attentive on the measure of their financial objectives e.g. Returns on investments, returns on equity, returns on sales, sales growth, revenue and non-financial measures (subjective) e.g. customer loyalty and satisfaction, employee satisfaction, increasing staff, brand awareness, performance relative to competitors and owners' satisfaction. (Richard et al, 2008). For any organization to grow its performance, multiple strategies have to be used which may include innovations, marketing and competitiveness procedures. A common strategy recently used is the focus on Corporate Social Responsibility.

\subsection{Equity Bank}

Equity bank is a notable bank that become a fully-fledged commercial bank in 2014 operating under the name Equity Bank Limited (EBL). Two years later, it was subsequently included in the Nairobi Securities exchange and it is currently the largest bank in the Kenyan Market. It has 
grown from a small enterprise to the most powerful financial service provider in the region with additional branches in five other countries in Africa, namely, Congo, Rwanda, South Sudan, Tanzania and Uganda (Equity Bank Official Website, 2017).In early 2013, equity bank was ranked top in the best Bank in Kenya Tier 1 a list that includes all banks with assets worth over 150 million Kenya shillings. At the time, Equity bank owed assets worth an excess of 252 Kenyan Billion shillings. It was also recognized and awarded banking institution that charges the lowest transactional charges due to its affordability and inclusivity. At the time, Equity bank was also awarded as the bank with the highest deposit base with the base at the time being more than 70 billion Kenyan Shillings. The Wings to Fly project has so far collected 2.8 Billion shillings of which so far, 1.9 billion has been spent on educating over 20,000 beneficiaries. Companies that tend to devote minimal amount of their resources to CRS usually have a high ROI thus showing an inverted U shaped rapport between CTS and an organization's performance Bowman \& Haire, 2014). Without taking into account the empirical factors, CSR should generally improve an organization's financial performance. And yet, these findings are far removed from the unique situation that developing countries face and particularly financial institutions like Equity Bank. This study consequently intends to fill the significant gap that exists in exploring the influence of corporate social responsibility on organizational performance of Equity Bank through their Wings to fly program.

\section{STATEMENT OF THE PROBLEM}

Apart from the soft benefits linked to CSR there is no information on the financial linkage between the cost of CSR and performance of the bank. Consequently, it become important to also look at the theoretical ramifications that follow the empirical understanding of CSR and bank performance and this study thus hoped to fill this significant gap. On a global scale, Marcia, Markus and Oakley, (2013) did a study on corporations in the USA to find out the benefits of CSR to their organizations with their findings being that larger institutions tend to be remunerated for being socially responsible. However, their research did consider the effect of CSR on the organizations' performance considering both measurements in terms of financial and non-financial indicators.

Carmen-Pilar, Rosa and Lisa, (2011) on their part looked at service sector companies in Norway and asserted that size of the firm was precisely corresponding to its CSR asset. According to studies done in Kenya, there is a relationship between the organization's profitability and CSR (Okoth, 2012). According to Okiro, Omoro and Kinyua (2013) in their study on influence of CSR on commercial banks financial performance; they found out that organizations can create a foundation and an avenue for improving their product worth and promote themselves by embracing Corporate Social Responsibility. The study however did not measure any performance elements and was thus incomplete. Further, based on the findings of these studies, identifying the components of the CSR programmes in a specified organization are the link between CSR and the cooperate performance. For this study's purposes, the philanthropic, benefit salient, ratio of CSR contributions and financial aspects of CSR was the study's main focus. Additionally, most studies given were unsuccessful in showing the force that CSR possesses on a firm's outcome; thus, the presence of a gap in knowledge. This study thus, intended to close the gap by examining the force exerted by this corporate social responsibility activities on an organization's outcome. 


\section{OBJECTIVE OF THE STUDY}

The study evaluated the influence of Corporate Social Responsibility on the performance of an organization with reference to the Equity Bank.

The study also sought to specifically consider the following specific objectives:

i. To establish the influence of philanthropic CSR activities on organizational performance

ii. To determine the influence of benefit salience in the corporate social responsibility on organizational performance.

iii. To assess the influence of CSR contributions on organizational performance

iv. To evaluate the influence of financial focused CSR activities on organizational performance

\section{THEORETICAL REVIEW}

This study was based on three major theories which are the Triple Bottom Line Theory, the Stakeholder Theory and finally the Fiduciary Capitalism Theory

\subsection{Triple Bottom Line Theory}

The triple bottom line (TBL) theory was initially significantly espoused by Elkington (1999) who argued that this theory is a central component of the CSR platform from which organizations can operate. Henriques and Richardson, (2014) in articulating the tenets of triple bottom line (TBL) theory and the link to CSR argued that there is a close rapport between corporate responsibilities and economic, social, and environmental bottom lines (Karaibrahimoglu, 2010). It's argued that most organizations see the economic bottom line as the universal area of importance in any business and is always pictured and is determined by the financial statistics. On the social bottom line aspect, the idea is presented as issues the entail the resource available and how stakeholder make use of them while the environmental bottom line is about the natural capital utilized to create tasks for organizations in their CSR activities (Henriques\& Richardson, 2014). Therefore, "sustainability accounting" is incorporated create a groundwork for the financial influences of sustainability revolving around the central concept for an organization. The basic argument for this accounting framework is to calculate the worth of a firm accruing from their efforts to the society within the context of TBL (Karaibrahimoglu, 2010). Participating in environmental and social implications of an organization, instead of focusing on monetary aspects only, has recently gained significant attention. This theory thus became important in articulating the influence of corporate responsibilities on organizational performance; a performance that is constantly and closely related to economic, social, and environmental bottom lines of such businesses. For this study, the financial and philanthropic elements were closely tied to this theory as it linked the elements to getting work done from top of the organization to the bottom of the community.

\subsection{Stakeholder Theory}

Stakeholder theory was first postulated by Mitchell (1997) and is presently a major impression for explaining how businesses and the society are related. (Carroll \& Buchholtz, 2013). It is the presence of multiple parties whose relationships are bound equally and reciprocate depending on the relationship or any contradicting interests existing within the firm. "In stakeholder literature there are some wide definitions that attempt to make specifications verifiable by reality and experience, that basically any one can be affected by and in return affect a business's actions" 
(Mitchell, 1997, pg 854). In other fields of business literature, a business is privileged to its purpose and its surroundings (Carroll \& Buchholtz, 2013) which elucidates the diverse understandings of stakeholders in an organization. Here, generally, society is viewed as a succinct macro environment that also entails the outside surrounding. A stakeholder-based method portends diverse advantages for stakeholders in groups or organizations (Perrini, 2005). An example is, each group of stakeholders are given a go ahead to identify and successfully complete their duties having in mind the company's policies and activities. Apart from that, it permits companies to observe their business's irregular and diversified environment in order to meet the needs of the society the firm operates in and ensure its satisfaction (Perrini, 2005).According to Roberts, (2013), stakeholders have vested interests and specific expectations of the organizations. These interestsinclude Authorizers, business partners, external influencers and customers. Donaldson and Preston, (2005) asserted that the stakeholder theory is grouped into three unique categories of normative, descriptive and instrumental forces. This theory was appropriate for this study has it involved all stakeholders from equity bank to the community and looked at how they harnessed corporate social responsibility to benefit the community.

\subsection{Fiduciary Capitalism Theory}

Fiduciary Capitalism Theory of CSR as postulated by Friedman \& Friedman, (1962), which is touted to culminate to shareholder value-oriented administration, asserts succinctly that the main objective of a firm is seeking profit coupled with the expansion of the economic value for its shareholders is the only social responsibility a business should strive to meet (Friedman \& Friedman, 1962). The stakeholders are the most important in a business set up therefore ones their needs have been met then the firm has no other responsibilities. According to Friedman (1962), in such an economy, the only social responsibility of business; to use the available resources and engage in activities that will only lead to an increase in profits so long as it doesn't break any rules, which means, engaging in open and free competitions, without unethical means. In the same vein, companies like Equity bank have a fiduciary duty to the society. In answer to that duty, they engage in CSR activities to not only improve their bottom line but to also do good to the society; this is the reason this theory was relevant to the present study.

\section{Conceptual Framework}

The conceptual framework offers a diagrammatic illustration of the link between the independent variables of ratio of CSR contributions, financial CSR and philanthropic CSR and the dependent variable of performance of Equity Bank. The IVs are assumed to influence positively the performance of the bank if done infectively and vice-versa as seen in Figure 1 below. 


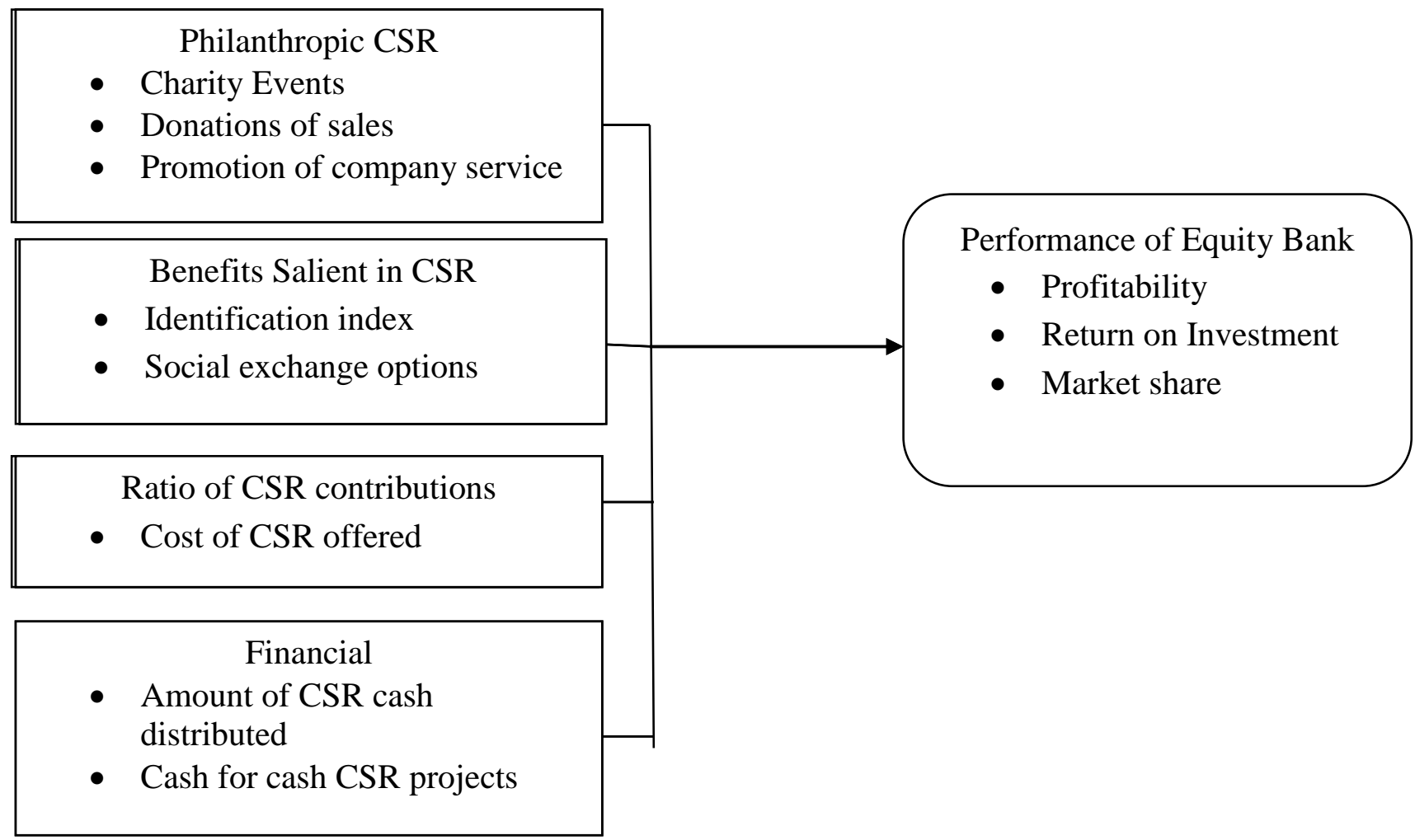

\section{RESEARCH METHODOLOGY}

This study adopted a descriptive research design which, according to Kothari (2014), is structured to review a number of logical sub-units or units of analysis within organizations. Morris and Wood (2011) acknowledge the benefit of descriptive design particularly when the purpose of the study is to gain a wider understanding of the context of the research and processes being enacted. In this study, all the 238-management staff across the 9 departments of Equity Bank was the target population. The management staff was selected because they were on the upper echelons of decision making and as a result, they understood the issues of CSR and how they influence performance as illustrated in Table 1.

Table 1: Target Population

\begin{tabular}{ll}
\hline Department & Management Staff \\
\hline 1. Finance & 38 \\
2. Corporate Strategy & 22 \\
3. Innovation and Payments & 19 \\
4. Human Capital and Administration & 33 \\
5. Corporate and SME Banking & 29 \\
6. Strategic Partnerships, Collaborations and Investor & 16 \\
Relations. & \\
7. Operations and Customer Experience & 32 \\
8. Credit & 34 \\
9. Special Projects & 15 \\
Total & $\mathbf{2 3 8}$ \\
\hline
\end{tabular}


The formula, $\mathrm{n}_{\mathrm{a}}=(\mathrm{n} \times 100) / \mathrm{re} \%$, advocated by Saunder, Lewis and Thornhill (2011) was used to estimate the actual sample size for the study, where:

$\mathrm{n}_{\mathrm{a}-}$ is the actual sample size; $\mathrm{n}$ is the minimum estimated sample size, and re\% is the estimated response rate expressed as a percentage. Based on this, and with an estimated $75 \%$ response rate the actual sample size was 105 respondents as shown in Table 2:

Table 2 Sample Size

\begin{tabular}{lll}
\hline Department & $\begin{array}{l}\text { Management } \\
\text { Staff }\end{array}$ & Sample Size \\
\hline 1. Finance & 38 & $38 / 238 \times 105=16$ \\
2. Corporate Strategy & 22 & $22 / 238 \times 105=10$ \\
3. Innovation and Payments & 19 & $19 / 238 \times 105=9$ \\
4. Human Capital and Administration & 33 & $33 / 238 \times 105=14$ \\
5. Corporate and SME Banking & 29 & $29 / 238 \times 105=12$ \\
6. Strategic Partnerships, Collaborations and & 16 & $38 / 238 \times 105=8$ \\
$\quad$ Investor Relations. & & \\
7. Operations and Customer Experience & 32 & $38 / 238 \times 105=14$ \\
8. Credit & 34 & $38 / 238 \times 105=15$ \\
9. Special Projects & 15 & $38 / 238 \times 105=7$ \\
Total & $\mathbf{2 3 8}$ & $\mathbf{1 0 5}$ \\
\hline
\end{tabular}

This study used both primary data and secondary data in the form of document analysis and structured questionnaires. The study included secondary data by examining documents, especially the financial reports like profit and loss results. Primary data that was gathered through questionnaires. The study employed a Likert-style rating, and quantity questions to get responses from the management staff. The collected, coded and cleaned and then analyzed using descriptive statistics and inferential statistics - Both the Pearson correlation and Linear Regression Techniques was used to test the research hypotheses. The following regression model was adopted

Regression Model: $\alpha_{0}=\beta_{0}+\beta_{1} X_{1}+\beta_{2} X_{2}+\beta_{3} X_{3}+\beta_{4} X_{4}+$ e, Where $\alpha_{0}$ - Performance, $X_{1}$ Philanthropic, $X_{2}$-Benefit Salient, $X_{3}$ - CSR Contributions, $X_{4}$ - Financial, e- Error term

\section{RESEARCH FINDINGS}

\subsection{Correlation Analysis}

The relationship between variables was tested using Pearson correlation and the findings are shown on Table 3. The study variables had a positive correlation with the dependent variable with Financial focused CSR having the maximum correlation of $(r=0.720, p<0.01)$ then Philanthropic CSR with a correlation of $(r=0.685 \mathrm{p}<0.01)$ followed closely by benefit salient with a correlation of $(r=0.615 p<0.01)$, CSR contributions had the slenderest correlation of $(r=$ $0.588 \mathrm{p}<0.01$ ). This indicates that all the variables are statistically significant at the $99 \%$ confidence interval level 2-tailed. Wong and Hiew (2005) have asserted that correlation coefficient value $(r)$ should desirably be between 0.5 and 0.8 as that is where strong values are highlighted. Anything below is either medium or weak. 


\begin{tabular}{|c|c|c|c|c|c|c|}
\hline & & $\begin{array}{c}\text { Organizatio } \\
\text { nal } \\
\text { Performance }\end{array}$ & $\begin{array}{c}\text { Philanthropi } \\
\text { c CSR }\end{array}$ & $\begin{array}{l}\text { Benefit } \\
\text { salient }\end{array}$ & $\begin{array}{c}\text { CSR } \\
\text { contributions }\end{array}$ & $\begin{array}{c}\text { Financial } \\
\text { focused } \\
\text { CSR }\end{array}$ \\
\hline \multirow[t]{2}{*}{$\begin{array}{l}\text { Philanthropic } \\
\text { CSR }\end{array}$} & $\begin{array}{l}\text { Pearson } \\
\text { Correlation }\end{array}$ & $.685^{* *}$ & 1 & & & \\
\hline & Sig. (2-tailed) & .000 & & & & \\
\hline \multirow[t]{2}{*}{ Benefit salient } & $\begin{array}{l}\text { Pearson } \\
\text { Correlation }\end{array}$ & $.615^{* *}$ & $543^{* *}$ & 1 & & \\
\hline & Sig. (2-tailed) & .001 & .000 & & & \\
\hline \multirow[t]{2}{*}{$\begin{array}{l}\text { CSR } \\
\text { contributions }\end{array}$} & $\begin{array}{l}\text { Pearson } \\
\text { Correlation }\end{array}$ & $.588^{* *}$ & $.420^{* *}$ & $.207^{* *}$ & 1 & \\
\hline & Sig. (2-tailed) & .000 & .000 & .012 & & \\
\hline \multirow[t]{2}{*}{$\begin{array}{l}\text { Financial } \\
\text { focused CSR }\end{array}$} & $\begin{array}{l}\text { Pearson } \\
\text { Correlation }\end{array}$ & $.720^{* *}$ & $.215^{* *}$ & .298 & $.537^{* *}$ & 1 \\
\hline & Sig. (2-tailed) & .000 & .004 & .000 & .001 & \\
\hline
\end{tabular}

**. Correlation is significant at the 0.01 level (2-tailed).

\subsection{Regression Analysis}

To check for the variable predictive power, regression was done and the results are as seen on Table 4.11, 4.12, 4.13. Regression was used to test the following hypotheses:

$\mathrm{H}_{01}$ : Philanthropic CSR activities do not have notable dominance on the performance of an organization.

$\mathrm{H}_{02}$ : Benefit salience in the corporate social responsibility does not have notable dominance on the performance of an organization.

$\mathrm{H}_{03}$ : CSR contributions do not have significant influence on organizational performance

$\mathrm{H}_{04}$ : Financial focused CSR activities do not have notable dominance on the performance of an organization.

Table 4: Model Summary ${ }^{b}$

\begin{tabular}{|c|c|c|c|c|c|}
\hline Model & $\mathrm{R}$ & R Square & Adjusted R Square & $\begin{array}{l}\text { Std. Error of the } \\
\text { Estimate }\end{array}$ & Durbin-Watson \\
\hline 1 & $.872^{\mathrm{a}}$ & .768 & .702 & .186 & 2.370 \\
\hline
\end{tabular}

\section{b. Dependent Variable: Organizational Performance}

From table 4, it is clear that, bearing in mind the positive nature of the value, that the results of the regression analysis show a positive direction of the correlation relationship between observed value and the predicted value that is shown by the dependent variable. 
International Journal of Current Aspects, Volume 3, Issue II, 2019, PP 186-198, ISSN 2616-6976

iJCAB

Table 5 ANOVA ${ }^{b}$

\begin{tabular}{|c|c|c|c|c|c|c|}
\hline Model & & Sum of Squares & Df & Mean Square & $\mathrm{F}$ & Sig. \\
\hline \multirow[t]{3}{*}{1} & Regression & 212.703 & 4 & 48.096 & 104.301 & $.001^{\mathrm{a}}$ \\
\hline & Residual & 10.878 & 207 & .694 & & \\
\hline & Total & 223.581 & 211 & & & \\
\hline
\end{tabular}

a. Predictors: (Constant), Philanthropic CSR, benefit salient, CSR contributions, Financial focused CSR

\section{b. Dependent Variable: Organizational Performance}

The generated $\mathrm{F}$-statistics $(\mathrm{F}=104.301$.) showed a significance at 5 per cent level (Sig. $\mathrm{F}<0.05)$, thus showing that the model was fit and thus, there is statistically significant relationship between Philanthropic CSR, benefit salient, CSR contributions, Financial focused CSR, and Organizational Performance.

Table 6 Coefficients

\begin{tabular}{lcccccc}
\hline & \multicolumn{2}{c}{$\begin{array}{c}\text { Unstandardized } \\
\text { Coefficients }\end{array}$} & \multicolumn{2}{c}{$\begin{array}{c}\text { Standardized } \\
\text { Coefficients }\end{array}$} & & \\
\cline { 2 - 5 } Model & B & Std. Error & Beta & t & Sig. \\
\hline (Constant) & 2.667 & .371 & .277 & 7.698 & .001 \\
Philanthropic CSR & .375 & .068 & .353 & 5.908 & .000 \\
Benefit salient & .267 & .064 & .184 & 2.513 & .004 \\
CSR contributions & .376 & .064 & .334 & 4.393 & .000 \\
Financial focused CSR & .281 & .162 & .223 & 3.087 & .002 \\
\hline
\end{tabular}

a. Dependent Variable: Organizational Performance

The generated $t$-value of constant $(t=7.698)$ shows a significance at .000 per cent level (Sig. F $<$ 0.05), thus making the fitness confirmation positive. Therefore, there is statistically significant relationship between Philanthropic CSR, benefit salient, CSR contributions, Financial focused CSR, and Organizational Performance. The results show that all the variables were statistically significant because they had a $\mathrm{p}$ value less than $5 \%$. Further based on the beta results the study thus interprets the model as: $\alpha_{0}=2.667+0.375\left(\mathrm{X}_{1}\right)+0.267\left(\mathrm{X}_{2}\right)+0.376\left(\mathrm{X}_{3}\right)+0.281\left(\mathrm{X}_{4}\right)+\mathrm{e}$. This implies that for every unit increase in Philanthropic CSR Organizational Performance increases with 0.375 units, for any increase in benefit salient, Organizational Performance increases with 0.267 units; for any increase in CSR contributions, Organizational Performance increases with 0.376 units and finally for any increase in Financial focused CSR, Organizational Performance increases with 0.281 units.

This regression result goes in tandem with reviewed literature that argued like Marcia, Otgontsetseg and Hassan (2013) in a descriptive survey investigated CSR in its philanthropic format that primarily, CSR in its philanthropic format was necessary for the development of 
system quality and improvement of companies. But they also mentioned that CSR in its philanthropic. Asforth and Mael, (2009) did a case study in a private company in Australia and tried to explain the benefit salient in CSR activities. They identified organizational identification defined as the degree to which organizational members perceive that an organization shares their defining attributes as a major benefit salient from CSR. This goes in tandem with social identity theory that asserts that persons prefer a high prestigious firm that helps to amass self-esteem than those that don't (Ashforth \& Mael, 2009). Ongolo (2012) explored the link between ratio of CSR contributions and market share. The findings confirmed a significant link existing between CSR contributions ratio and market share. Businesses that had staked more on CSR experienced a high income. He also realized that both CSR and market share index moved in tandem hence signifying a positive correlation coefficient. Also, in agreement, Kitzmuellery and Shimshack (2012), investigated succinctly the economic viewpoints on CSR, and came to the realization that penchants shown by specified firms characterized the key factors affecting the CSR applied. When social shareholders preferences are evident, many firms use this strategic CSR to maximize their profits, however nonprofit organizations tend to use CSR to satisfy shareholders social ambitions.

Thus, the four hypotheses:

Table 7: Hypotheses Testing

\begin{tabular}{llll}
\hline Hypothesis & Test & Results & Remarks \\
\hline $\begin{array}{l}\text { H01: Philanthropic CSR does not affect } \\
\text { Organizational Performance at Equity }\end{array}$ & Regression .000 & Significant & Rejected \\
$\begin{array}{l}\mathrm{H}_{02} \text { : Benefit salient does not affect Organizational } \\
\text { Performance at Equity }\end{array}$ & Regression .004 & Significant & Rejected \\
$\begin{array}{l}\mathrm{H}_{03} \text { CSR contributions does not affect } \\
\text { Organizational Performance at Equity }\end{array}$ & Regression .000 & Significant & Rejected \\
$\begin{array}{l}\mathrm{H}_{04} \text { : Financial focused CSR does not affect } \\
\text { Organizational Performance at Equity }\end{array}$ & Regression .002 & Significant & Rejected \\
\hline
\end{tabular}

\section{CONCLUSIONS}

The study concludes that philanthropic Corporate Social Responsibility, benefit salient, CSR contributions and financial focused CSR significantly positively influence organizational performance of commercial banks in Kenya and specifically Equity Bank. Thus, CSR is worthy investment for any commercial banks or organization that seeks to positively improve organization performance.

\section{RECOMMENDATIONS}

Based on the study objectives and the accruing conclusions, the study makes the following recommendations: Equity bank management should continue to invest more in the corporate social responsibility aspect done to make the life of beneficiaries better in terms of education, health and other humanistic endeavors. Equity bank management should improve on strategies 
that improves on the desired outcomes that accrue out of CSR activities and improve by seminars and involvement actions how the employees feel about CSR enough to warrant motivation to better productivity by them. Equity bank management should improve on the amount of money invested in CSR every year against the yearly earnings of the banks. This will help to entrench CSR even more and improve organizational performance. Equity bank management should enact actions and events like rebates to customers and low interests done by the bank using the money to engage in CSR. These will also work to improve organizational performance of the bank.

\section{REFERENCES}

Angelidis J. P., Massetti, B. L. \& Magee-Egan, P. (2008). Does Corporate Social Responsibility Orientation Vary by Position in the Organizational Hierarchy? Review of Business Spring, 28(3), 23-32.

Balabanis, G., Philips, H. \&Lyall, J. (1998). Corporate Social Responsibility and Economic Performance in the Top British Companies: Are they Related? European Business Review, 98(1), 25-44.

Barney, J. B. (2011). Firm resources and sustained competitive advantage. Journal of Management, 17, 99 - 120.

Briloff, R. (1972). Unaccountable Accounting. New York: Harper \& Row.

Bourke, P. (1989). Concentration and other determinants of bank profitability in Europe, North America and Australia.Journal of Banking and Finance 13, 65-79.

Bowen, H. R. (1953). Social Responsibilities of the Businessman. New York: Harper \& Row.

Bowman, E. \&Haire, M. (2014).A Strategic Posture toward Corporate Social Responsibility.California Management Review, 18(2), 49-58.

Carmen - Pilar, M. B., Rosa, R. M. \& Lisa, G. J. D. (2011). Do the Best European Socially Responsible Companies Perform Better Financially? Unpublished project, University of Barcelona.

Carroll, A. B. (2011). The pyramid of corporate social responsibility: Toward the moral management of organizational stakeholders. Business Horizons, 39-48.

Elkington, J. (1999). Cannibals with forks: The triple bottom line of 21 st century business. Gabriola Island, BC: New Society Publishers.

Galbreath, J. (2012). Building Corporate Social Responsibility into Strategy.European Business Review, (2), 109-127.

Gichana, O. B. (2014). A Survey of Corporate Social Responsibility Practice by Kenyan Companies: A Case for Companies Listed in the Nairobi Stock Exchange. An unpublished MBA Research project, University of Nairobi.

Jensen, M. C. \&Meckling, W. H. (2009). Theory of the Firm: Managerial Behavior, Agency Costs and Ownership Structure. Journal of Financial Economics,3(4), 305-360.

Lantos, G. (2002). The Ethicality of Altruistic Corporate Social Responsibility.Journal of Consumer Marketing, (3), 205-230.

Marcia M. C., Otgontsetseg, E. \& Hassan T. (2013). Corporate Social Responsibility and its Impact on Financial Performance: Investigation of U.S. Commercial Banks. Unpublished research paper, Department of Finance, Bentley University, Waltham, US.

Okiro, K., Omoro, N. \&Kinyua, H. (2013). Investment in Corporate Social Responsibility and Sustained Growth In Commercial Banks In Kenya. Journal of Emerging Issues in Economics, Finance and Banking. An Online International Monthly Journal,3(2), 10571064. 
Okoth, D. O. (2012). The Influence of Corporate Social Responsibility on the Financial Performance of Commercial Banks in Kenya.An unpublished MBA Research project, University of Nairobi.

Orlitzky, M. (2013). Does firm size confound the relationship between corporate social performance and firm financial performance? Journal of Business Ethics, 33, 167-180.

Rumelt, R. P. (1987). Theory, Strategy and Entrepreneurship. The Competitive challenge: Strategies for industrial innovation and renewal. Cambridge, Mass: Ballinger Publishers, $137-157$.

Saunders, M., Lewis, P. \& Thornhill, A. (2009) Research Methods for Business Students. Pearson, New York.

Zairi, M. (2000).Social Responsibility and Impact on Society. The TQM Magazine, (3), 172178.

This is an open-access article published and distributed under the terms and conditions of the $(c)$ EY $_{\mathrm{B}}$ Creative Commons Attribution 4.0 International License of United States unless otherwise stated. Access, citation and distribution of this article is allowed with full recognition of the authors and the source.

Authors seeking to publish with an International Peer Reviewed Journal should consider www.ijcab.org by writing to the Editor at editor@ijcab.org. List of our Journals are Available at www.ijcab.org/journals 